\title{
CEFTRIAXONE-INDUCED PERIORBITAL EDEMA
}

\author{
VINAYAKA ANUHYA ${ }^{1}$, VEENA NAYAK ${ }^{1 *}$, KEERTHI SOMU ${ }^{2}$, SEREENE ROSE THOMSON ${ }^{1}$, SUJATHA BS ${ }^{2}$
}

${ }^{1}$ Department of Pharmacology, Kasturba Medical College, Manipal Academy of Higher Education, Manipal - 576 104, Karnataka, India. ${ }^{2}$ Department of OBG, Kasturba Medical College, Manipal Academy of Higher Education, Manipal - 576 104, Karnataka, India. Email: veena.nayak@manipal.edu

Received: 12 June 2018, Revised and Accepted: 05 September 2018

ABSTRACT

Cephalosporins are widely prescribed antibiotics for common infections and also used for prophylactic measures. Ceftriaxone is a third-generation cephalosporin which is known to cause hypersensitivity reactions presenting in various manifestations. Periorbital edema is a rare presentation of adverse drug reaction produced by ceftriaxone. Here, we report one such adverse drug reaction produced by ceftriaxone.

Keywords: Cephalosporin, Hypersensitivity reaction, Naranjo scale.

(c) 2019 The Authors. Published by Innovare Academic Sciences Pvt Ltd. This is an open access article under the CC BY license (http://creativecommons. org/licenses/by/4. 0/) DOI: http://dx.doi.org/10.22159/ajpcr.2019.v12i1.25293

\section{INTRODUCTION}

Cephalosporins are the second most important $\beta$-lactams for treating infectious diseases. Ceftriaxone is a third-generation cephalosporin, commonly used antibiotic. It is widely used for the treatment of septicemia and approved for the treatment of meningitis, including meningitis caused by pneumococci and meningococci [1]. The common adverse drug reactions to cephalosporins are hypersensitivity reactions, anaphylaxis, urticaria, or maculopapular rashes which are IgE mediated [2]. The frequency of hypersensitivity reactions due to ceftriaxone is between $1 \%$ and 3\% [3]. There were previous case reports of hypersensitivity and the presentation is mostly anaphylactic or rashes. Here, we present a case of ceftriaxone-induced periorbital edema which is a rare presentation.

\section{CASE REPORT}

A 27-year-old female para 1, living 1 (P1, L1) with 40 weeks of gestation came with leaking per vaginum. On examination, cephalopelvic disproportion with fetal distress was present, so emergency lower uterine segment cesarean section was done. The surgery was uneventful and she delivered a female baby of $3.2 \mathrm{~kg}$ who cried immediately at birth and had a good Apgar score. A test dose of $0.1 \mathrm{ml}$ of ceftriaxone was given intradermally pre-operative, which was non-reactive. Postoperatively, injection ceftriaxone $2 \mathrm{~g}$ i.v was given, following which she developed periorbital edema after $2 \mathrm{~h}$ with breathing difficulty. Ceftriaxone was withdrawn. On examination, there was bilateral erythema around the eyes, chemosis, and massive periorbital edema as shown in the Fig. 1.

Injection dexamethasone $8 \mathrm{mg}$ i.v stat, injection furosemide $20 \mathrm{mg}$ i.v stat, injection pheniramine maleate $45.5 \mathrm{mg}(2 \mathrm{~mL})$ i.v stat, and injection hydrocortisone $100 \mathrm{mg}$ i.v stat were given as treatment. The patient did not have any previous history of atopy or allergy to any other substances. Ophthalmology and medicine consultations were sought. Blood urea and serum creatinine levels were $21 \mathrm{mg} / \mathrm{dl}$ and $0.6 \mathrm{mg} / \mathrm{dl}$, respectively. T3, T4, and thyroid-stimulating hormone were within normal limits throughout her pregnancy and also postpartum. A differential diagnosis of periorbital cellulitis was made, which was then ruled out by a thorough ophthalmological examination as there was no local rise of temperature, no skin color change, and no tenderness, and the edema was bilateral, it was diagnosed as a case of ceftriaxone-induced periorbital edema. After stopping ceftriaxone, she was started on injection gentamicin $160 \mathrm{mg}$ i.v and ciprofloxacin eye drops bilaterally 4 times a day with cold compression over the swelling.
Her concomitant medications included intravenous oxytocin 10 units, pantoprazole $40 \mathrm{mg}$, tramadol $50 \mathrm{mg}$, and promethazine $28 \mathrm{mg}$.

\section{DISCUSSION}

Ceftriaxone has a broad spectrum of activity against Gram-positive and Gram-negative aerobic and some anaerobic bacteria. Ceftriaxone has a greater activity over the first- and second-generation cephalosporins against Gram-negative bacteria. It selectively and irreversibly inhibits bacterial cell wall synthesis by binding to penicillin-binding proteins that catalyze the cross-linking of the peptidoglycan polymers forming the bacterial cell wall [4]. Ceftriaxone is administered intravenously or intramuscularly. For adults, recommended dosage is $1-2 \mathrm{~g}$ once daily. It is indicated for the treatment of pediatric, lower respiratory tract infections, and skin, bone, and joint infections. It is also found effective in intra-abdominal, obstetric and gynaecological infections $[5,6]$.

In this case, ceftriaxone was given initially as a test dose before the surgery and also postoperatively for chemoprophylaxis. When the test dose was given, there was no allergic reaction. However, later, when the entire dose was given, the patient developed gross periorbital edema with chemosis which is an unusual presentation of the adverse reaction due to ceftriaxone. Earlier cases of hypersensitivity type-1 with

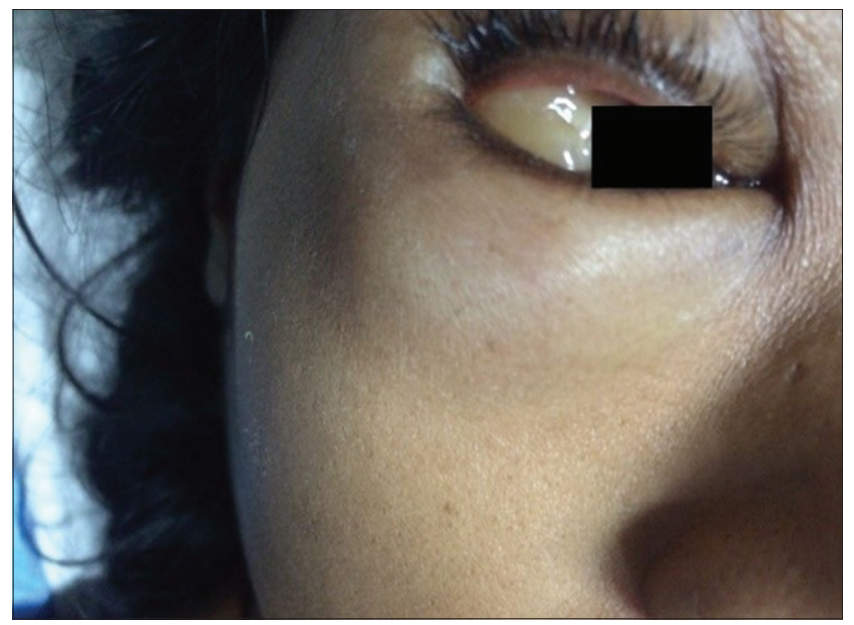

Fig. 1: Periorbital edema 
ceftriaxone were reported with maculopapular rashes, urticaria, and angioedema which is an IgE-mediated allergy. The possible mechanism is thought to be development of $\operatorname{IgE}$ antibodies against antigenic determinants that are unique to $\beta$-lactams. The core structure of these has a four-membered $\beta$-lactam ring and there could be sensitization to this core structure or its metabolite or the side chain groups [7].

The causality assessment score based on Naranjo's algorithm was 7. Therefore, it is a "probable" adverse drug reaction [8].

\section{CONCLUSION}

Periorbital edema is a rare presentation among the other types of hypersensitivity reactions associated with ceftriaxone. Hence, clinicians should be cognizant of such an occurrence.

\section{AUTHORS' CONTRIBUTIONS}

All authors have contributed to concept, structure, and processing of the article.

\section{CONFLICTS OF INTEREST}

There are no conflicts of interest.

\section{REFERENCES}

1. Deck DH, Winston LG. Beta-Lactam and other cell wall-and membrane-active antibiotics. In: Katzung BG, Trevor AJ, editors. Basic and Clinical Pharmacology. 13 ${ }^{\text {th }}$ ed. New York: McGraw-Hill; 2015. p. 778 .

2. Kelkar PS, Li JT. Cephalosporin allergy. N Engl J Med 2001;345:804-9.

3. Ernst MR, van Dijken PJ, Kabel PJ, Draaisma JM. Anaphylaxis after first exposure to ceftriaxone. Acta Paediatr 2002;91:355-6.

4. Petri WA Jr. Penicillins cephalosporins, and other $\beta$-lactam antibiotics. In: Brunton LL, Chabner BA, Knollman BJ, editors. Goodman and Gilman's the Pharmacological Basis of Therapeutics. $12^{\text {th }}$ ed. New York: McGraw-Hill; 2011. p. 1505-20.

5. Gowthami B, Spurthi T, Afreen S. Drug utilization evaluation of antibiotics in general medicine department of a tertiary care hospital. Int J Pharm Pharm Sci 2016;8:302-4.

6. Nhac-vu H, Ngoc-van T. Injectable cephalosporins use in Vietnamese hospitals: A descriptive cross-sectional multi center study. Int J Pharm Pharm Sci 2017;9:135-8.

7. Dickson SD, Salazar KC. Diagnosis and management of immediate hypersensitivity reactions to cephalosporins. Clin Rev Allergy Immunol 2013;45:131-42.

8. Naranjo CA, Busto U, Sellers EM, Sandor P, Ruiz I, Roberts EA, et al. A method for estimating the probability of adverse drug reactions. Clin Pharmacol Ther 1981;30:239-45. 